\title{
Association between cadmium exposure and diabetes mellitus risk: a prisma-compliant systematic review and meta-analysis
}

\author{
Ming Wu $\mathbf{u}^{1, *}$, Jukun Song ${ }^{2, *}$, Chen Zhu ${ }^{3, *}$, Yadong Wang ${ }^{2}$, Xinhai Yin ${ }^{2}$, Guanglei \\ Huang', Ke Zhao', Jianguo Zhu ${ }^{4}$, Zhuhui Duan ${ }^{5}$ and Lingkai Su ${ }^{5}$ \\ ${ }^{1}$ Department of Emergency Medicine, Guizhou Provincial People's Hospital, Guizhou, China \\ ${ }^{2}$ Department of Oral and Maxillofacial Surgery, Guizhou Provincial People's Hospital, Guizhou, China \\ ${ }^{3}$ Guiyang Hospital of Stomatology, Medical College, Zunyi Medical College, Guiyang, China \\ ${ }^{4}$ Department of Urology, Guizhou Provincial People's Hospital, Guizhou, China \\ ${ }^{5}$ Affiliated Hospital of Stomatology, Medical College, Zhejiang University, Hangzhou, China \\ *These authors contributed equally to this work
}

Correspondence to: Lingkai Su, email: 0016730@zju.edu.cn

Keywords: cadmium; diabetes mellitus

Received: July 03, 2017 Accepted: September 21, $2017 \quad$ Published: October 20, 2017

Copyright: Wu et al. This is an open-access article distributed under the terms of the Creative Commons Attribution License 3.0 (CC BY 3.0), which permits unrestricted use, distribution, and reproduction in any medium, provided the original author and source are credited.

\section{ABSTRACT}

Cadmium (Cd) is a pollutant with multiple adverse health effects: cancer, renal dysfunction, osteoporosis and fracture, and cardiovascular disease. Several population-based studies found an association between $\mathrm{Cd}$ and diabetes mellitus (DM), but this association is inconsistent with other research. We conducted metaanalysis to examine relationship between urinary/blood Cd exposure and DM risk. Pertinent studies were identified by searching PubMed and Embase databases, and combined odds ratio (OR) and corresponding $95 \%$ confidence interval (CI) were applied to evaluate said association. Meta-analysis showed that high $\mathrm{U}-\mathrm{Cd}$ exposure is not correlated with $D M$ risk $(O R=1.19 ; 95 \% \mathrm{CI}=0.83-1.71)$, and high $\mathrm{B}-\mathrm{Cd}$ exposure is also not associated with increased risk of DM (OR $=1.16 ; 95 \% \mathrm{CI}=0.84-1.62)$ in the general population. Subgroup and sensitivity analysis proved similar results, with little evidence of publication bias. This meta-analysis suggests that high U-Cd/BCd exposure may not be risk factor for DM in general populations. However, large prospective studies are needed to confirm this finding.

\section{INTRODUCTION}

Burden of diabetes is increasing globally. In 2008, 347 million people worldwide suffered from diabetes, and this number is well above earlier estimations from the World Health Organization [1, 2]. The number of people with diabetes is expected to reach 366 million worldwide in 30 years; therefore, preventative actions are needed to mediate this global issue [3]. Type II diabetes mellitus (T2DM) is primarily characterized by metabolic disorders and abnormally high blood sugar (hyperglycemia) because of low insulin levels with or without abnormal resistance to insulin action; T2DM accounts for $90 \%$ of diabetes cases $[4,5]$. Hence, novel preventable risk factors must be identified immediately. Established risk factors for T2DM include age, family history, genetic variants, obesity, and physical inactivity $[2,6,7]$. Beyond these established risk factors, unidentified environmental factors may influence development of DM [8-10].

Health problems related to heavy metal exposure caused worldwide concern recently. Cadmium (Cd) is a naturally occurring, non-essential toxic metal and also an industrial and agricultural pollutant [11]. Cd exhibits high rate of soil-to-plant transfer; therefore, general population is primarily exposed to $\mathrm{Cd}$ via food ingestion and tobacco smoke inhalation [12]. Observational studies suggest association between body burden of $\mathrm{Cd}$ and T2D and/or prediabetes and showed positive [13-21] and null associations $[8,22-31]$. These studies used small sample sizes, which possibly hindered detection of correlation. Therefore, public health will be significantly affected by increased body burden of $\mathrm{Cd}$ exposure and common 
incidence of DM and risk factors for its development. Therefore, we systematically performed meta-analysis to evaluate association between urinary/blood $\mathrm{Cd}$ exposure and DM risk. Systematic search and review processes were conducted according to the Preferred Reporting Items for Systematic Reviews and Meta-Analyses Statement criteria [32].

\section{RESULTS}

\section{Literature search, study characteristics, and quality}

Following development of our search strategy, 767 records were initially identified. A total of 191 duplicate studies were excluded, 576 were subsequently screened, and 408 were excluded because titles and abstracts did not fit our criteria. Thirty full-text articles were reviewed for further assessment. Five articles were excluded because they were duplicate publications $[14,15,22,24,28]$; another five were excluded because $\mathrm{Cd}$ content was measured [33-37], three studies were excluded because the outcome was gestational diabetes mellitus [17, 18, 25], three were reviews [38-40], two were excluded because outcomes were related to chronic kidney disease [41] or renal glomerular damage [42] and one was excluded because the exposure was $\mathrm{Cd}$ in the toenail [13]. Finally, eleven studies met meta-analysis criteria and were included (Figure 1).
Table 1 summarizes individual characteristics of eleven included articles (two cohort studies [29, 30], and nine cross-sectional studies $[8,16,19-21,23,26,27$, 31]). The articles were published from 2007 to 2017. Of the 11 studies, seven were published in Asia [16, 19, 21, 23, 26, 27, 31], another two were published in Europe [29, 30], one was published in North American [8] and one in Australia [20]. Numbers of DM patients ranged from 28 to 1,346 across all included studies. Seven studies used urinary $\mathrm{Cd}$ as biomarker for long-term $\mathrm{Cd}$ exposures [8, $16,19,20,23,27,30]$, whereas five articles evaluated $\mathrm{Cd}$ exposure levels by estimating blood $\mathrm{Cd}[21,26$, 29-31]. The diabetes mellitus identification and adjusted covariates are shown in Table 2. Diabetes was defined based on self-reported physician diagnosis [8] and/or medication plus fasting plasma glucose $[16,19-21,23$, $26,27,30,31]$, oral glucose tolerance test (OGTT) [30], or local diabetes register [29]. Most studies examined the association between $\mathrm{Cd}$ exposure and risk of DM [8, $19,20,23,26,27,29]$, only three studies explored the relationship between $\mathrm{Cd}$ exposure and risk of type II DM $[16,30,31]$. Adjusted effect estimates were determined for most included studies, except for one [20]. Most risk estimates were adjusted for age $(n=9)[8,16,19,21$, $23,26,27,29,31]$, smoking status $(n=9)[8,16,21,23$, $26,27,29-31]$ and alcohol consumption $(n=6)[8,16$, $23,26,27,31]$, Some studies were controlled for gender $(n=6)[8,16,19,21,26,27,31]$, body mass index $(n=$ 4) $[16,19,21,23,27]$ and waist circumference $(n=3)$

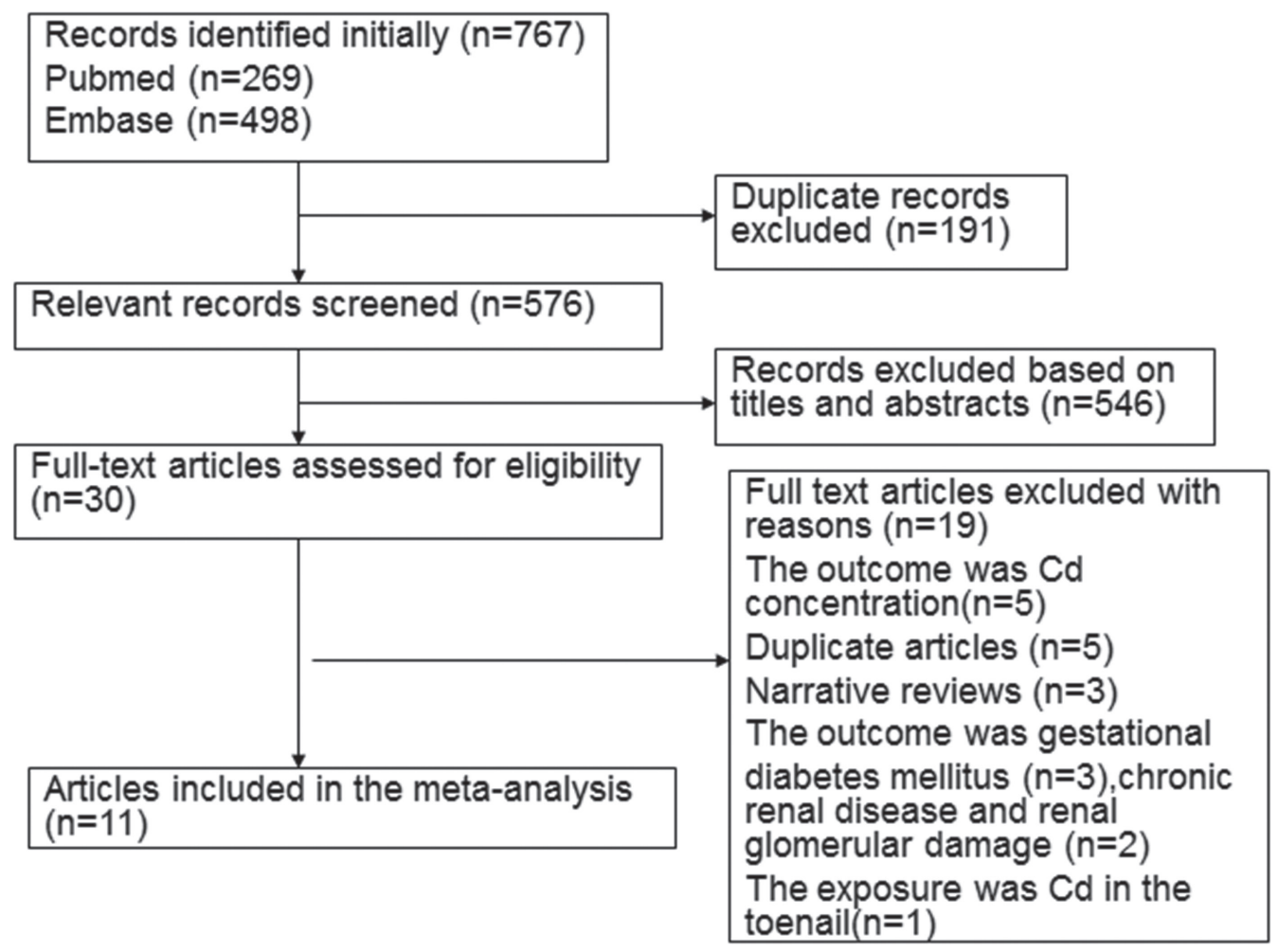

Figure 1: Flow diagram of the literature included. 
Table 1: Characteristics of cohort/cross-sectional studies included in the meta-analysis

\begin{tabular}{|c|c|c|c|c|c|c|c|c|c|c|}
\hline Study & Year & Country & Study design & $\begin{array}{l}\text { No. of } \\
\text { cases }\end{array}$ & $\begin{array}{l}\text { Sample } \\
\text { size }\end{array}$ & Sex & $\begin{array}{l}\text { Age, Median } \\
\text { (Range), years }\end{array}$ & Exposure & Exposure assessment & $\begin{array}{l}\text { Study } \\
\text { period } \\
\text { (years) }\end{array}$ \\
\hline Haswell-Elkins & 2007 & Australia & $\begin{array}{l}\text { A cross-sectional } \\
\text { study }\end{array}$ & 28 & 126 & $\begin{array}{l}\text { Female and } \\
\text { male }\end{array}$ & $36.2(15-76)$ & $\mathrm{U}-\mathrm{Cd}$ & $\begin{array}{l}\text { An inductively coupled } \\
\text { mass spectrometry }\end{array}$ & 1996 \\
\hline Swaddiwudipong & 2010 & $\begin{array}{l}\text { Thailand } \\
\text { (Mae Sot } \\
\text { District) }\end{array}$ & $\begin{array}{l}\text { A cross-sectional } \\
\text { study }\end{array}$ & 348 & 5273 & $\begin{array}{l}\text { Female and } \\
\text { male }\end{array}$ & $52.8 \pm 11.9(\geq 35)$ & U-Cd & $\begin{array}{l}\text { A graphite tube atomic- } \\
\text { absorption spectrometer. }\end{array}$ & 2009 \\
\hline Barreqard & 2013 & Swede & $\begin{array}{l}\text { A cross-sectional } \\
\text { and prospective } \\
\text { cohort study }\end{array}$ & 68 & 2595 & Female & NA $(>64)$ & $\begin{array}{l}\text { U-Cd,B- } \\
\mathrm{Cd}\end{array}$ & $\begin{array}{l}\text { An inductively coupled } \\
\text { plasma-mass spectrometry }\end{array}$ & $2001-2003$ \\
\hline Moon & 2013 & Korea & $\begin{array}{l}\text { A cross-sectional } \\
\text { study (KNHANES) }\end{array}$ & 333 & $\begin{array}{l}F: 1588 \\
M: 1596\end{array}$ & $\begin{array}{l}\text { Female and } \\
\text { male }\end{array}$ & NA $(\geq 30)$ & $\mathrm{B}-\mathrm{Cd}$ & $\begin{array}{l}\text { Graphite-furnace atomic } \\
\text { absorption spectrometry } \\
\text { and Zeeman background } \\
\text { correction. }\end{array}$ & 2009-2010 \\
\hline Borne & 2014 & $\begin{array}{l}\text { Swede } \\
\text { (Malmo" } \\
\text { in } \\
\text { southern } \\
\text { Sweden) }\end{array}$ & $\begin{array}{l}\text { A prospective } \\
\text { cohort study } \\
\text { (MDC) }\end{array}$ & 622 & 4585 & $\begin{array}{l}\text { Female and } \\
\text { male }\end{array}$ & NA (46-67) & $\mathrm{B}-\mathrm{Cd}$ & $\begin{array}{l}\text { An inductively coupled } \\
\text { plasma mass spectrometry } \\
\text { with an octopole reaction } \\
\text { system. }\end{array}$ & 1991-1996 \\
\hline Son & 2015 & Korea & $\begin{array}{l}\text { A cross-sectional } \\
\text { study (HESRAM) }\end{array}$ & 158 & 719 & $\begin{array}{l}\text { Female and } \\
\text { male }\end{array}$ & $59.1(40-70)$ & $\mathrm{U}-\mathrm{Cd}$ & $\begin{array}{l}\text { A flameless atomic } \\
\text { adsorption spectrometry } \\
\text { and graphite } \\
\text { furnace attached to } \\
\text { atomic absorption } \\
\text { spectrophotometer. }\end{array}$ & 2008-2011 \\
\hline Tangvarasittichai & 2015 & Thailand & $\begin{array}{l}\text { A cross-sectional } \\
\text { study }\end{array}$ & 30 & 535 & $\begin{array}{l}\text { Female and } \\
\text { male }\end{array}$ & $\mathrm{NA}(\geq 30)$ & $\mathrm{U}-\mathrm{Cd}$ & $\begin{array}{l}\text { A graphite tube atomic- } \\
\text { absorption spectrometer. }\end{array}$ & 2010-2011 \\
\hline Liu & 2016 & China & $\begin{array}{l}\text { A cross-sectional } \\
\text { study }\end{array}$ & 102 & 1493 & $\begin{array}{l}\text { Female and } \\
\text { male }\end{array}$ & $\begin{array}{l}\text { DM: } 47 \pm 6.7 \\
\text { Normoglycemia } \\
\text { group: } 41.8 \\
\pm 8.7\end{array}$ & U-Cd & $\begin{array}{l}\text { An inductively coupled } \\
\text { plasma-mass spectrometry }\end{array}$ & 2016 \\
\hline Menke & 2016 & USA & $\begin{array}{l}\text { A cross-sectional } \\
\text { study (NHANES) }\end{array}$ & 1364 & 9447 & $\begin{array}{l}\text { Female and } \\
\text { male }\end{array}$ & $\begin{array}{l}\text { Diabetes: } 58.6 \\
\pm 0.54 ; \text { No } \\
\text { diabetes: } 45.6 \\
\pm 0.30\end{array}$ & $\mathrm{U}-\mathrm{Cd}$ & $\begin{array}{l}\text { An inductively } \\
\text { coupled plasma } 8 \text { mass } \\
\text { spectrometry }\end{array}$ & 1999-2010 \\
\hline $\mathrm{Nie}$ & 2016 & China & $\begin{array}{l}\text { A cross-sectional } \\
\text { SPECT-China study }\end{array}$ & 565 & 5544 & $\begin{array}{l}\text { Female and } \\
\text { male }\end{array}$ & NA $(18-\geq 69)$ & $\mathrm{B}-\mathrm{Cd}$ & $\begin{array}{l}\text { A graphite furnace atomic } \\
\text { absorption spectrometry. }\end{array}$ & 2016 \\
\hline $\mathrm{Li}$ & 2017 & China & $\begin{array}{l}\text { A cross-sectional } \\
\text { study }\end{array}$ & 122 & 559 & $\begin{array}{l}\text { Female and } \\
\text { male }\end{array}$ & NA (40-92) & $\mathrm{B}-\mathrm{Cd}$ & $\begin{array}{l}\text { An inductively coupled } \\
\text { plasma-mass spectrometry }\end{array}$ & 2014-2016 \\
\hline
\end{tabular}

B-Cd, blood cadmium; U-Cd, urinary cadmium; NA, not available.

$[8,29,30]$, but few were adjusted for ethnicity $(n=$ 2) 8,19 , hypertension $(n=2)[23,27]$ and physical activity $(n=2)[26,27]$. None of the studies were adjusted for exposure to other heavy metals (such as arsenic and bisphenol).

Included studies generally showed good methodological quality. Newcastle-Ottawa Scale (NOS) scores ranged from 5 to 7 (Table 3). Mean NOS score was 6.2 .

\section{U-Cd concentration and risk of DM}

Seven studies examined the association of $\mathrm{U}-\mathrm{Cd}$ concentration with risk of DM. The overall OR was 1.19 times (odds ratio $(\mathrm{OR})=1.19 ; 95 \%$ confidence interval $(\mathrm{CI}=0.83-1.71)$ for the highest category of $\mathrm{Cd}$ exposure compared with lowest category with significant heterogeneity $\left(\mathrm{P}_{\text {for heterogeneity }}=0.001, I^{2}=73.2 \%\right)$ (Figure 2, Table 4). In sensitivity analysis, similar results were observed for DM risk; values ranged from $1.07(95 \% \mathrm{CI}=$ $0.76-1.52)$ with significant heterogeneity $\left(I^{2}=70.2 \% ; \mathrm{P}_{\text {for }}\right.$
$=0.005)$ (excluding the study by Tangvarasittichai et al. [16]) to $1.37(95 \% \mathrm{CI}=0.87-2.17)$ with significant heterogeneity $\left(I^{2}=74.2 \% ; \mathrm{P}_{\text {for heterogeneity }}=0.002\right)$ (excluding the study by Menke et al. [8]). Subgroup analysis stratified by geographic region and gender, study design, NOS score, adjustment for covariates, exposure type, and similar results for DM (Figure 3, Table 4).

\section{B-Cd concentration and risk of DM}

Five studies examined the association of $\mathrm{B}-\mathrm{Cd}$ concentration with risk of DM. The summary OR was 1.16 times (odds ratio $(\mathrm{OR})=1.16 ; 95 \%$ confidence interval $(\mathrm{CI}=0.84-1.62)$ for the highest category of $\mathrm{Cd}$ exposure compared with lowest category with low heterogeneity $\left(\mathrm{P}_{\text {for heterogeneity }}=0.011, I^{2}=69.2 \%\right)$ (Figure 2$)$. In sensitivity analysis, similar results were observed for DM risk; values ranged from $1.04(95 \% \mathrm{CI}=0.87-1.25)\left(I^{2}=9.7 \% ; \mathrm{P}_{\text {for }}\right.$ $=0.344$ ) (excluding the study by $\mathrm{Li}[31])$ to 1.26 (95\% CI: $0.84-1.90)$ with significant heterogeneity $\left(I^{2}=\right.$ $72.1 \% ; \mathrm{P}_{\text {for heterogeneity }}=0.013$ ) (excluding the study by Moon 


\section{Table 2: Diabetes mellitus identification, adjustment for covariates of cohort/cross-sectional studies}

included in the meta-analysis

\begin{tabular}{|c|c|c|c|}
\hline Author & year & Diabetes mellitus identification & Adjustment for covariates \\
\hline Haswell-Elkins & 2007 & $\begin{array}{l}\text { Diabetes was defined as a fasting blood glucose level of } 7.8 \\
\mathrm{mmol} / \mathrm{l} \text { or greater and/or a } 2 \mathrm{~h} \text { glucose test result over } 11.0 \\
\mathrm{mmol} / \mathrm{l} \text {. }\end{array}$ & NA \\
\hline Swaddiwudipong & 2010 & $\begin{array}{l}\text { Diabetes was defined as fasting plasma glucose } \geq 126 \mathrm{mg} / \mathrm{dl} \text { on } 2 \\
\text { occasions or currently receiving anti-diabetic treatment. }\end{array}$ & $\begin{array}{l}\text { Adjusted for age, alcohol consumption, tobacco smoking, body mass index, } \\
\text { and hypertension. }\end{array}$ \\
\hline Barreqard & 2013 & $\begin{array}{l}\text { Diabetes was defined as FPG } \geq 6.1(\geq 110) \text { and/or } 2 \mathrm{~h} \text { post } \\
\text { glucose load } \geq 11.1 \mathrm{mmol} / 1(\geq 200 \mathrm{mg} / \mathrm{dl}) \text { measured at two } \\
\text { occasions (OGTT). }\end{array}$ & $\begin{array}{l}\text { Adjusted for by pack years of smoking, waist circumference, serum } \\
\text { adiponectin. }\end{array}$ \\
\hline Moon & 2013 & $\begin{array}{l}\text { Diabetes was defined as fasting plasma glucose levels at } 126 \mathrm{mg} / \\
\mathrm{dl} \text {, they were on diabetes treatment, or they reported a history of } \\
\text { physician-diagnosed diabetes. }\end{array}$ & $\begin{array}{l}\text { Adjusted for age, sex, region, smoking, alcohol consumption, and regular } \\
\text { exercise. }\end{array}$ \\
\hline Borne & 2014 & $\begin{array}{l}\text { Incident cases of diabetes were identified from national and local } \\
\text { diabetes registers. }\end{array}$ & Adjusted for age, waist circumference, and smoking status. \\
\hline Son & 2015 & $\begin{array}{l}\text { Diabetes was defined as the existence of past diabetes history, } \\
\text { for cases in which treatment of diabetes resulted in measurement } \\
\text { of more than } 126 \mathrm{mg} / \mathrm{dl} \text { in fasting blood glucose according to } \\
\text { diabetes diagnostic criteria in American Diabetes Association }\end{array}$ & $\begin{array}{l}\text { Adjusted for age (continuous), sex, ethnicity (non-Hispanic blacks, Mexican } \\
\text { Americans, and others vs. non-Hispanic white), and BMI (continuous). }\end{array}$ \\
\hline Tangvarasittichai & 2015 & $\begin{array}{l}\text { Diabetes was defined as fasting glucose concentration of } \geq 126 \\
\mathrm{mg} / \mathrm{dl} \text {, non-fasting glucose concentration of } \geq 200 \mathrm{mg} / \mathrm{dl} \text {, a self- } \\
\text { reported physician diagnosis, or medication use. }\end{array}$ & $\begin{array}{l}\text { Adjusted for diabetes, CKD, U-Protein } / \mathrm{g} \text { CT, Cal } / \mathrm{g} \text { CT, BMI, alcohol } \\
\text { drinking, smoking, gender, age. }\end{array}$ \\
\hline Liu & 2016 & $\begin{array}{l}\text { Diabetes was diagnosed when } \mathrm{FPG} \geq 7.0 \mathrm{mmol} / \mathrm{L} \text { or use of anti- } \\
\text { diabetic medications or as self-reported by physicians (the World } \\
\text { Health Organization guidelines). }\end{array}$ & $\begin{array}{l}\text { Adjusted for gender, age, BMI, smoking status, drinking status, physical } \\
\text { activity, education levels, urinary creatinine, hypertension, hyperlipidemia, } \\
\text { and urinary PAHs level. }\end{array}$ \\
\hline Menke & 2016 & $\begin{array}{l}\text { Diabetes was defined as a self-reported previous diagnosis of } \\
\text { diabetes or an } \mathrm{HbA} 1 \mathrm{c} \geq 6.5 \%(48 \mathrm{mmol} / \mathrm{mol}) \text {. }\end{array}$ & $\begin{array}{l}\text { Adjusted for age, race, ethnicity, sex, menopausal status, education, } \\
\text { income, smoking status, pack years smoked, alcohol consumption, waist } \\
\text { circumference, C-reactive protein, high alanine aminotransferase, high } \\
\text { gamma glutamyl transferase, daily calories consumed, percent of calories } \\
\text { from saturated fat, and urinary creatinine. }\end{array}$ \\
\hline $\mathrm{Nie}$ & 2016 & $\begin{array}{l}\text { Diabetes was defined as a previous diagnosis by health care } \\
\text { professionals or } \mathrm{FPG} \geq 7.0 \mathrm{mmol} / \mathrm{L} \text {. }\end{array}$ & $\begin{array}{l}\text { Adjusted for age (continuous), sex, residence area, economic status, current } \\
\text { smoker, hypertension, dyslipidemia, estimate glomerular filtration rate } \\
\text { (continuous), blood lead (continuous), and BMI (continuous) }\end{array}$ \\
\hline $\mathrm{Li}$ & 2017 & $\begin{array}{l}\text { Diabetes was defined as random plasma glucose concentrations } \\
\geq 11.1 \mathrm{mmol} / \mathrm{L} \text { plus symptoms of diabetes, } 2 \text {-hour post-load oral } \\
\text { glucose tolerance test }(\mathrm{OGTT}) \geq 11.1 \mathrm{mmol} / \mathrm{L} \text {, or fasting plasma } \\
\text { glucose }(\mathrm{FPG}) \geq 7.0 \mathrm{mmol} / \mathrm{L} \text {, an } \mathrm{HbA} 1 \mathrm{c} \geq 6.5 \% \text {. }\end{array}$ & Adjusted for age, gender, BMI, family history, smoking and drinking status. \\
\hline
\end{tabular}

FPG, fasting plasma glucose; OGTT, oral glucose tolerance test; HbA1c, Hemoglobin A1c.

[26]). Subgroup analysis stratified by geographic region and study design, NOS score, adjustment for covariates, exposure type, and similar results for DM (Table 5).

\section{Publication bias}

Due to relatively limited number of eligible studies, we only conduct publication bias between $\mathrm{U}-\mathrm{Cd}$ concentration and risk of DM, but not in B-Cd concentration. There was little evidence of publication bias with Egger funnel plot asymmetry $(P=0.368)$ and Begg rank correlation tests $(P=0.446)$. Funnel plot symmetry (Figure 4) was also examined.

\section{DISCUSSION}

$\mathrm{Cd}$ is an ubiquitous industrial and naturally occurring environmental contaminant resulting from anthropogenic activity; it poses toxic effects on lungs, liver, testicles, kidneys, and bone tissues [11]. Recently, $\mathrm{Cd}$ exposure was associated with multiple adverse health effects, including osteoporosis and fractures [43, 44], renal dysfunction [45, 46], atherosclerotic plaques [47, 48], cancer $[49,50]$, and cardiovascular diseases $[51,52] . \mathrm{Cd}$ is primarily considered a nephrotoxicant; however, numerous short- and long-term in vivo Cd exposure models showed that $\mathrm{Cd}$ can cause hyperglycemia and disrupt glucose homeostasis in experimental animals [39, 53]. Significant relationship was observed between $\mathrm{Cd}$ exposure and prevalence of prediabetes and/or T2DM8, [13-29]. Using National Health and Nutrition Examination Survey (NHANES) data, urine Cd was positively associated with diabetes $[14,15]$, but no correlation was detected in further studies [8]. In a cross-sectional study of Korean general population, $\mathrm{B}-\mathrm{Cd}$ was associated with metabolic syndrome [26] but not diabetes [26]. In a case-control study in Pakistan, participants with diabetes exhibited higher levels of hair $\mathrm{Cd}$ than those without [54]. No statistically significant association was found between $\mathrm{Cd}$ exposure and diabetes in heavily Cd-contaminated area in Thailand [22-24]. However, in a study from the same group, diabetes prevalence significantly increased in subpopulation with continually high $\mathrm{Cd}$ exposure [55]. In three prospective studies, $\mathrm{Cd}$ exposure was unrelated 
Table 3: Quality assessment of eligible studies based on newcastle-ottawa scale

\begin{tabular}{llccc}
\hline \multicolumn{1}{c}{ Author } & year & Selection & Comparability & Exposure \\
\hline Haswell-Elkins & 2007 & 2 & 0 & 2 \\
Swaddiwudipong & 2010 & 3 & 2 & 1 \\
Barreqard & 2013 & 3 & 1 & 2 \\
Moon & 2013 & 3 & 2 & 2 \\
Borne & 2014 & 3 & 1 & 2 \\
Son & 2015 & 3 & 2 & 1 \\
Tangvarasittichai & 2015 & 3 & 2 & 2 \\
Liu & 2016 & 3 & 2 & 2 \\
Menke & 2016 & 3 & 2 & 2 \\
Nie & 2016 & 3 & 2 & 2 \\
Li & 2017 & 3 & 2 & 1 \\
\hline
\end{tabular}

Study

ID

OR $(95 \% \mathrm{Cl})$

\section{U-Cd}

Barreqard (2013)

Haswell-Elkins (2007)

Son (2015)

Menke (2016)

Tangvarasittichai (2015)

Liu (2016)

Swaddiwudipong (2010)

Subtotal $(\mathrm{I}$-squared $=73.2 \%, p=0.001)$

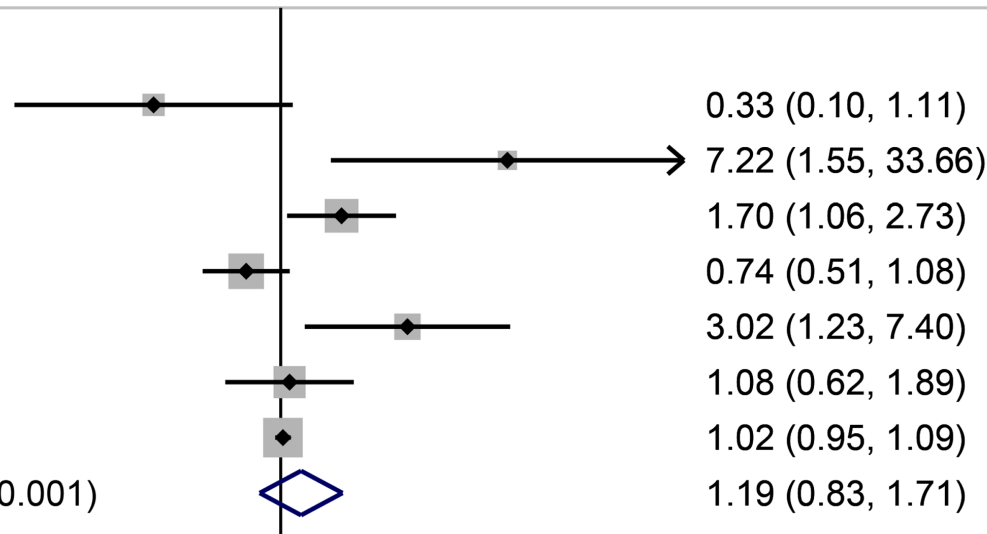

$\mathrm{B}-\mathrm{Cd}$

Moon (2013)

Barreqard (2013)

Borne (2014)

Nie (2016)

Li (2017)

Subtotal $(\mathrm{I}$-squared $=69.2 \%, p=0.011)$

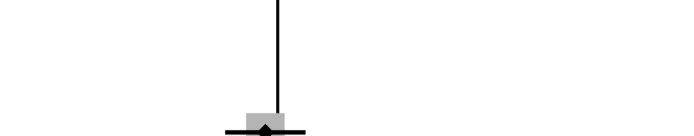

$0.90(0.63,1.27)$

$0.38(0.10,1.50)$

$1.11(0.82,1.50)$

$1.13(0.88,1.46)$

$2.51(1.49,4.24)$

$1.16(0.84,1.62)$

NOTE: Weights are from random effects analysis

$\begin{array}{llr}1 & 1 & \\ .0297 & 1 & 33.7\end{array}$

Figure 2: Forest plot for the association between U-Cd/B-Cd exposure and DM risk. 
to development of diabetes in two studies [29, 30] but correlation was observed in one study [13]. The most compelling evidence came from cross-sectional study by Menke et al. (2016), who used data from NHANES (1999-2010) to assess whether increased urinary cadmium (U-Cd) was associated with impaired T2D in the United States [8]. However, these studies included modest sample sizes, and magnitude of association varied among studies, with OR ranging from 0.74 (95\% CI: $0.51-1.09)$ to 7.22
(95\% CI: 1.52-33.04) and wide CI. Therefore, magnitude was limited by low precision of risk estimates. These epidemiological studies showed absence of comprehensive assessment in $\mathrm{Cd}$ exposure. Therefore, we conducted comprehensive meta-analysis to investigate the association between $\mathrm{Cd}$ exposure and DM risk.

In this meta-analysis, we analyzed associations between urinary/blood $\mathrm{Cd}$ exposure and DM risk. The present study is the first to provide comprehensive insights

Study

ID

OR $(95 \% \mathrm{Cl})$

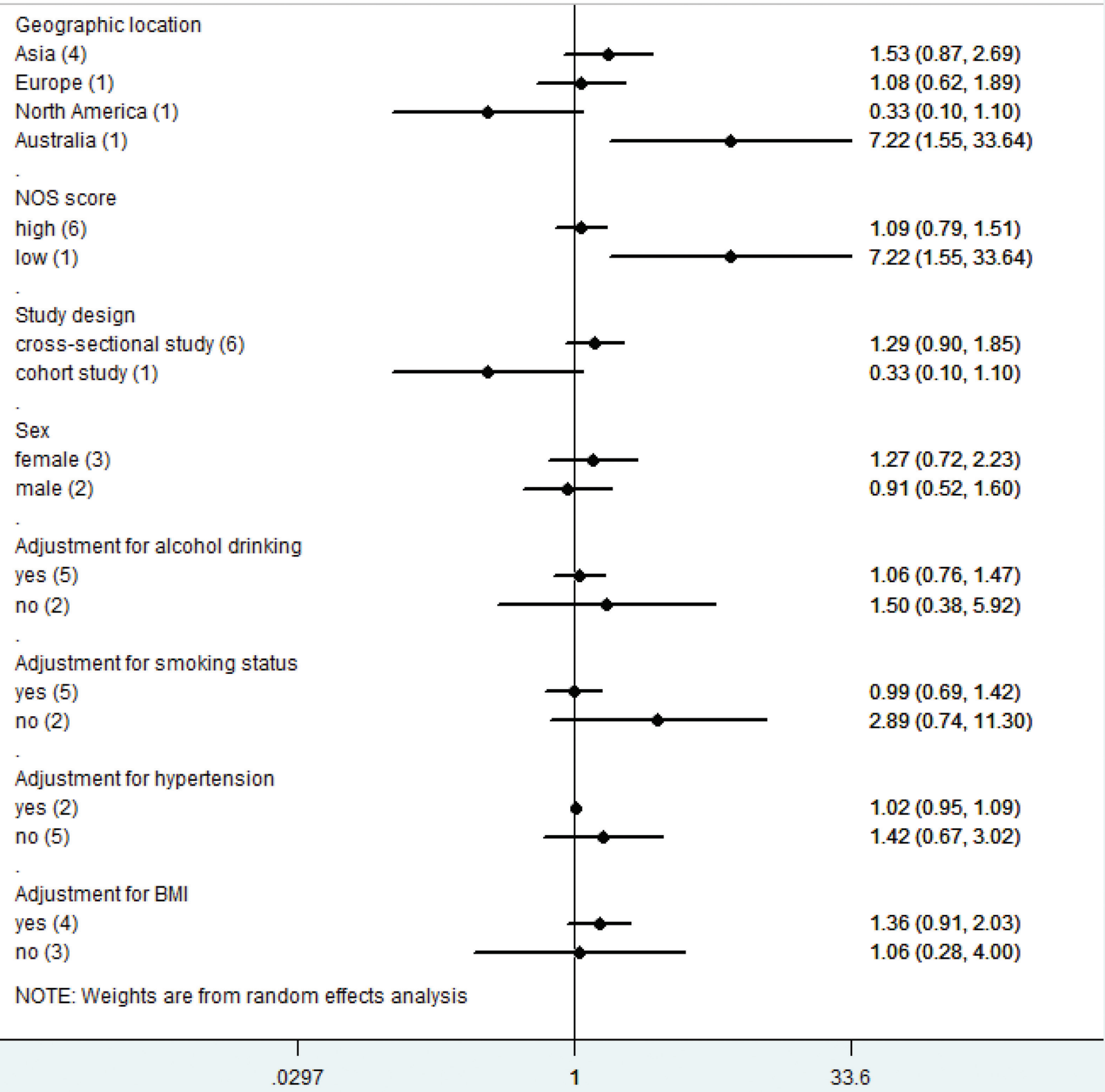

Figure 3: Subgroup analysis for U-Cd exposure and DM risk. 
Table 4: Results of subgroup analysis between $\mathrm{U}-\mathrm{Cd}$ concentration and risk of DM

\begin{tabular}{|c|c|c|c|c|c|}
\hline & Studies, $\mathbf{N}$ & OR $(95 \%$ CI $)$ & $P$-value & $P$ for heterogeneity & $I^{2}(\%)$ \\
\hline Total & 7 & $1.19(0.83-1.71)$ & 0.334 & 0.001 & 73.2 \\
\hline \multicolumn{6}{|l|}{ Geographic location } \\
\hline Asia & 4 & $1.53(0.87-2.68)$ & 0.142 & 0.007 & 79.7 \\
\hline North America & 1 & $1.08(0.62-1.89)$ & 0.120 & NA & NA \\
\hline Europe & 1 & $0.33(0.10-1.11)$ & 0.073 & NA & NA \\
\hline Australia & 1 & $7.22(1.55-33.66)$ & 0.012 & NA & NA \\
\hline \multicolumn{6}{|l|}{ NOS score } \\
\hline High & 6 & $1.09(0.79-1.51)$ & 0.596 & 0.006 & 69.1 \\
\hline Low & 1 & $7.22(1.55-33.66)$ & 0.012 & NA & NA \\
\hline \multicolumn{6}{|l|}{ Study design } \\
\hline Cross-sectional study & 6 & $1.29(0.90-1.85)$ & 0.160 & 0.002 & 73.7 \\
\hline Cohort study & 1 & $0.33(0.10-1.11)$ & 0.073 & NA & NA \\
\hline \multicolumn{6}{|l|}{ Gender } \\
\hline Female & 3 & $1.27(0.72-2.22)$ & 0.747 & 0.157 & 46.0 \\
\hline Male & 2 & $0.91(0.52-1.60)$ & 0.410 & 0.037 & 77.1 \\
\hline \multicolumn{6}{|c|}{$\begin{array}{l}\text { Adjusted for confounders } \\
\text { or important risk factors }\end{array}$} \\
\hline \multicolumn{6}{|l|}{ Alcohol drinking } \\
\hline yes & 5 & $1.06(0.76-1.47)$ & 0.748 & 0.038 & 64.3 \\
\hline no & 2 & $1.50(0.38-5.91)$ & 0.559 & 0.006 & 80.4 \\
\hline \multicolumn{6}{|l|}{ Smoking status } \\
\hline yes & 5 & $0.99(0.69-1.41)$ & 0.948 & 0.020 & 65.8 \\
\hline no & 2 & $2.89(0.74-11.32)$ & 0.128 & 0.079 & 67.7 \\
\hline \multicolumn{6}{|l|}{ Hypertension } \\
\hline yes & 2 & $1.02(0.95-1.09)$ & 0.549 & 0.843 & 0.0 \\
\hline no & 5 & $1.42(0.67-3.03)$ & 0.363 & 0.000 & 81.6 \\
\hline \multicolumn{6}{|l|}{ BMI } \\
\hline yes & 4 & $1.36(0.91-2.02)$ & 0.133 & 0.020 & 69.6 \\
\hline no & 3 & $1.06(0.28-3.99)$ & 0.927 & 0.007 & 80.1 \\
\hline
\end{tabular}

OR, odds risk; CI, confidence interval; High, NOS score of $\geq 6$; Low, NOS score of $<6$; NA, not available.

into effects of $\mathrm{Cd}$ exposure and DM-associated risks. Using random-effects model, 10 observational studies were included, and overall results proved that high $\mathrm{Cd}$ exposure is not associated with increased DM risk among the general population.

Results from subgroup analyses indicated potential sources of heterogeneity; these sources include geographic region, study design, NOS scale quality, gender, adjusted confounders or important risk factors, and method of $\mathrm{Cd}$ assessment. Despite intrinsic limitations of observational studies, subgroup analysis provided notable results. When stratified by gender, association remained nonsignificant for both male and female. Cd concentrations in urine and whole blood are the most common biomarkers for $\mathrm{Cd}$ exposure. Therefore, in kidneys, urinary $\mathrm{Cd}$ mainly reflects $\mathrm{Cd}$ accumulation, which is determined by long- term exposure, whereas whole blood $\mathrm{Cd}$ demonstrates combined current and historical exposures. In subgroup analysis results, which were stratified using $\mathrm{Cd}$ exposure assessment, both urinary and blood $\mathrm{Cd}$ are not associated with increased DM risk. In epidemiological studies, the most common biomarker for $\mathrm{Cd}$ exposure may be urinary $\mathrm{Cd}$. However, using urinary or blood Cd levels limits measurement of $\mathrm{Cd}$ exposure. Internal or absorbed dose of $\mathrm{Cd}$ in renal cortex is higher than that of blood or urine $\mathrm{Cd}$ levels in measuring low-level and long-term $\mathrm{Cd}$ exposure, because $\mathrm{Cd}$ concentration in renal cortex accurately represents lifelong $\mathrm{Cd}$ exposure [56, 57]. However, none of considered studies measured $\mathrm{Cd}$ concentration in renal cortex in meta-analysis. Smoking tobacco cigarettes is a major potential source of $\mathrm{Cd}$ exposure in the general population, and DM risk is increased among smokers. 
Therefore, we performed subgroup analyses adjusted for smoking status in a multivariable model to minimize possible non-Cd mediated negative effects of tobacco smoking on blood glucose. Only five publications $[8,16$, $24,27,30]$ were adjusted for smoking status, and results showed that Cd exposure is not related to increased DM risk (Table 2).

Development of DM represents interaction of environmental exposures, lifestyle factors, and genetic predisposition. Pathogenesis of both diseases can be considered a continuum of dysglycemia with development of impaired insulin secretion and insulin resistance as common pathogenic link. Human tissue sample studies indicated that $\mathrm{Cd}$ may preferentially accumulate in pancreatic islets [58]. Mechanism of Cd-induced diabetes remains uncertain but possibly involves damage to insulinproducing $\beta$-cells in islets of Langerhans; in pancreas of Cd-exposed rats, such cells secrete substantially less insulin than unexposed ones [38, 39, 59]. In cultured rat pancreatic $\beta$-cells, $\mathrm{Cd}$ increased reactive oxygen species, induced oxidative stress, and catalyzed cell death [60]. Alternatively, either urinary excretion of
$\mathrm{Cd}$ or body burden of $\mathrm{Cd}$ in humans may be increased by diabetes-related changes in renal function or other pathophysiological aspects of impaired glucose tolerance (IGT).

The present meta-analysis exhibited several strengths. First, this study was the first to investigate association between Cd exposure and DM risk. Second, large sample size improved risk estimate accuracy and resulted in well-founded conclusions based on metaanalysis. Pooled estimates were robust across sensitivity and subgroup analyses, and publication bias was not detected. Conclusions from combined estimates were more reliable than from single studies because overall OR was based on large sample size and exhibited sufficient power.

Nevertheless, some limitations should be considered in the present meta-analysis. First, almost all related previous studies were cross-sectional or retrospective, except for four prospective studies. Cross-sectional and case-control studies have inherent limitations, such as selective bias and recall or memory bias. Therefore, large prospective studies are needed to confirm such findings. Second, evidence from

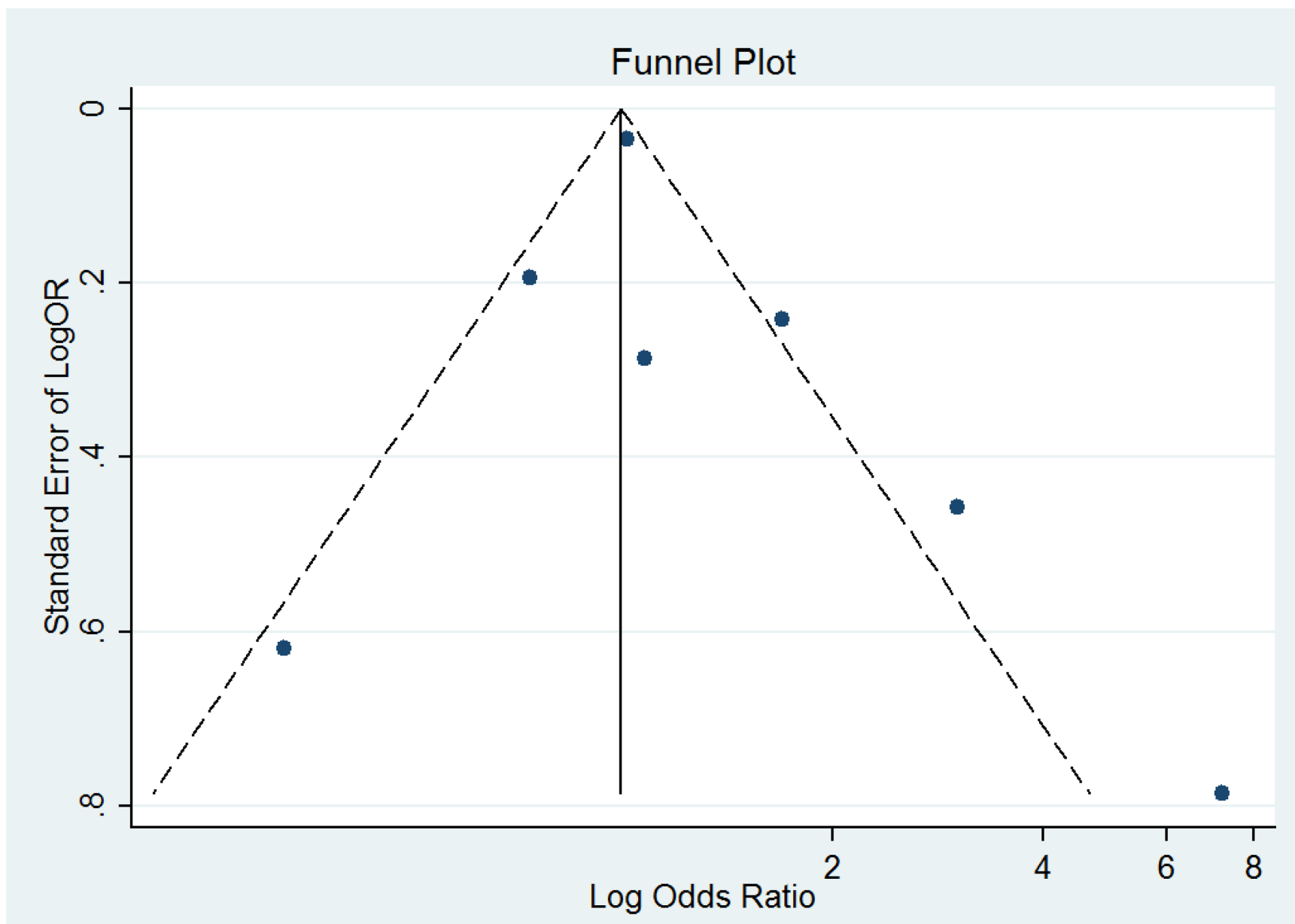

Figure 4: Funnel plot for publication bias analysis between U-Cd exposure and DM risk. 
Table 5: Results of subgroup analysis between B-Cd concentration and risk of DM

\begin{tabular}{|c|c|c|c|c|c|}
\hline & Studies, $N$ & OR (95\% CI) & $P$-value & $P$ for heterogeneity & $I^{2}(\%)$ \\
\hline Total & 5 & $1.16(0.84-1.62)$ & 0.361 & 0.011 & 69.2 \\
\hline \multicolumn{6}{|l|}{ Geographic location } \\
\hline Asia & 3 & $1.30(0.81-2.10)$ & 0.274 & 0.006 & 80.8 \\
\hline Europe & 2 & $0.81(0.31-2.11)$ & 0.663 & 0.135 & 55.2 \\
\hline \multicolumn{6}{|l|}{ NOS score } \\
\hline High & 5 & $1.16(0.84-1.62)$ & 0.361 & 0.011 & 69.2 \\
\hline Low & 0 & NA & NA & NA & NA \\
\hline \multicolumn{6}{|l|}{ Study design } \\
\hline Cross-sectional study & 3 & $1.30(0.81-2.10)$ & 0.274 & 0.006 & 80.8 \\
\hline Cohort study & 2 & $0.81(0.31-2.11)$ & 0.663 & 0.135 & 55.2 \\
\hline \multicolumn{6}{|c|}{$\begin{array}{l}\text { Adjusted for confounders } \\
\text { or important risk factors }\end{array}$} \\
\hline \multicolumn{6}{|l|}{ Alcohol drinking } \\
\hline yes & 2 & $1.47(0.54-4.03)$ & 0.451 & 0.001 & 90.2 \\
\hline no & 3 & $1.09(0.87-1.36)$ & 0.441 & 0.310 & 14.7 \\
\hline \multicolumn{6}{|l|}{ Smoking status } \\
\hline yes & 5 & $1.16(0.84-1.62)$ & 0.361 & 0.011 & 69.2 \\
\hline no & 0 & NA & NA & NA & NA \\
\hline \multicolumn{6}{|l|}{ Hypertension } \\
\hline yes & 1 & $1.13(0.88-1.46)$ & 0.344 & NA & NA \\
\hline no & 4 & $1.16(0.70-1.91)$ & 0.561 & 0.005 & 76.5 \\
\hline \multicolumn{6}{|l|}{ BMI } \\
\hline yes & 2 & $1.63(0.75-3.55)$ & 0.221 & 0.007 & 86.1 \\
\hline no & 3 & $0.97(0.72-1.29)$ & 0.821 & 0.256 & 26.7 \\
\hline
\end{tabular}

OR, odds risk; CI, confidence interval; High, NOS score of $\geq 6$; Low, NOS score of $<6$; NA, not available.

epidemiological studies indicated that $\mathrm{Cd}$ may exacerbate harmful renal effects of diabetes. However, owing to numerous other confounding environmental factors inherent in these epidemiological studies, difficulty arises from establishing cause-and-effect relationships. For example, increased probability of individuals becoming diabetic can be attributed to other environmental toxins, such as arsenic [61, 62] and bisphenol A [25, 63], or generalized inflammation and/or oxidative stress response [64]. Additional epidemiological studies are needed to rule out effects of such confounding variables on possible link between $\mathrm{Cd}$ and diabetes. Meanwhile, experimental study results in animals provided direct evidence for such a link $[65,66]$. Third, independent measurement errors were possibly present in most included studies because multiple metals in several included studies were examined in same urine/blood samples using same assays; results then were potentially misleading. Moreover, we cannot exclude possibility of false positives. Therefore, associations observed in meta-analysis should be further investigated in future studies. Fourth, although the similar feature of the included studies as the uniform feature was observed, the present meta-analysis lacks information on type of diabetes, and we could not differentiate type 1 from type $2 \mathrm{DM}$ in most included studies. We were also concerned that errors inevitably increase during DM diagnosis. Imprecise diagnosis of DM possibly attenuated true associations. Fifth, during follow-up, blood and urinary Cd levels probably declined. Therefore, in the present study, tentative $\mathrm{Cd}$ levels were possibly too low to have caused diabetogenic effects. Sixth, between-study heterogeneity is common in the meta-analysis, and it is essential to explore the potential sources of between-study heterogeneity. We also performed sensitivity analyses and subgroup analyses to determine the sources of heterogeneity, but heterogeneity was still observed. The potential for misclassification of exposure to cadmium and type 1/2 DM, Imprecise diagnosis of DM may contribute to the heterogeneity for all studies in the summary analysis.

In summary, the meta-analysis suggests that high $\mathrm{Cd}$ exposure may not be risk factor for DM in the general population. Further prospective studies should be conducted to determine possible association between lowlevel $\mathrm{Cd}$ exposure of general populations and increased risk of DM. 


\section{MATERIALS AND METHODS}

\section{Data source and search strategy}

Literature search was performed in April 2017 without any limitations. Primary sources were electronic databases of PubMed and EMBASE. To identify eligible studies, main searches employed various combinations of Medical Subject Headings (MeSH) and non-MeSH terms: "diabetes mellitus" OR "diabetes" combined with "cadmium". Reference lists of all studies and published systematic reviews and meta-analyses were screened to identify other potentially eligible studies. Main search was completed independently by investigators. Discrepancies were solved by consulting a researcher who was not involved in initial procedures.

\section{Eligibility criteria and study selection}

Studies were considered eligible for inclusion in meta-analysis when they met the following criteria: (1) exposure of interest was urinary/blood $\mathrm{Cd}$; (2) outcome of interest was DM risk; (3) study design was cohort, case control, or cross-sectional study; (4) RR, OR, or hazard risk (HR) with corresponding 95\% CI were reported or provided sufficient data to estimate crude OR, RR, or HR values with corresponding $95 \%$ CI. When included population was duplicated in more than one study, only the study with most comprehensive information was included.

\section{Data extraction and quality assessment}

Two reviewers extracted data independently using predefined data extraction form. Data included the following: first author, publication year, study design, country, total number of cases and subjects, sex, Cd exposure type, and diagnosis criteria for DM and adjusted variables. Adjusted OR was extracted as preference over non-adjusted OR. Unadjusted OR and CI were calculated whenever OR was not provided. When more than one adjusted OR was reported, the ratio with most number of adjusted variables was selected. Disagreements between authors (JKS and XHY) were resolved through discussion and consensus.

Methodological quality of included studies was assessed using NOS [67], which consists of three factors: patient selection, comparability of study groups, and assessment of outcomes. A score of 0-9 (allocated as stars) was allocated to each study. Observational studies achieving six or more stars were considered to be of high quality.

\section{Statistical analysis}

We used OR with $95 \% \mathrm{CI}$ as common measure across all studies. Cd-caused DM is a rare event. Therefore, in the cohort study, RR and HR were considered OR approximations. Two articles did not report overall risk estimates but instead separately presented results for men and women $[19,23]$. We combined results using fixed effects and included pooled risk estimates in primary analysis. In one study, OR failed to provide reliable results; therefore, we computed crude risk estimates and corresponding CI20. Aggregated results and 95\% CIs for effect sizes were calculated using inversevariance weighted random-effect meta-analysis, which incorporated both within- and between-study variabilities [68]. $I^{2}$ was used to assess heterogeneity across studies, with $I^{2}$ values of $0 \%, 25 \%, 50 \%$, and $75 \%$ representing no, low, moderate, and high heterogeneities, respectively. Sensitivity analysis was conducted to evaluate data robustness and stability by sequentially omitting one study on each turn. Subgroup analysis was stratified using study design, geographic region, gender, exposure type, adjustment for covariates, and NOS quality.

Consistent with publication bias, small study bias was evaluated using statistical tests (Begg rank correlation test [69] and Egger's linear regression test [70]) and visual examination of funnel plot of each trial effect size against standard error. Results indicated publication bias when $P<0.10$. All statistical analyses were conducted using Stata version 13.1 (Stata Corp, College Station, TX, USA).

\section{Author contributions}

J.K.S; G.L.H; X.H.Y; J.G.Z; M.W; L.K.S wrote the main manuscript text; J.K.S; G.L.H; X.H.Y; K.Z; Y.D.W; Z.C; L.K.S prepared Figures 1-4; J.K.S; G.L.H; J.G.Z; Z.H.D contributed data analysis; All authors reviewed the manuscript.

\section{CONFLICTS OF INTEREST}

The authors declare no competing financial interests.

\section{FUNDING}

Supported by the National Science Foundation of China (No. 81700972) and Joint fund project of Guizhou science and Technology Department (No. (2014) 7026).

\section{REFERENCES}

1. Danaei G, Finucane MM, Lu Y, Singh GM, Cowan MJ, Paciorek CJ, Lin JK, Farzadfar F, Khang YH, Stevens GA, Rao M, Ali MK, Riley LM, et al, and Global Burden of Metabolic Risk Factors of Chronic Diseases Collaborating Group (Blood Glucose). National, regional, and global trends in fasting plasma glucose and diabetes prevalence since 1980: systematic analysis of health examination surveys and epidemiological studies with 370 country-years and $2 \cdot 7$ million participants. Lancet. 2011; 378:31-40. 
2. Wild S, Roglic G, Green A, Sicree R, King H. Global prevalence of diabetes: estimates for the year 2000 and projections for 2030. Diabetes Care. 2004; 27:1047-53.

3. Meetoo D, McGovern P, Safadi R. An epidemiological overview of diabetes across the world. Br J Nurs. 2007; 16:1002-07.

4. Kahn SE, Zraika S, Utzschneider KM, Hull RL. The beta cell lesion in type 2 diabetes: there has to be a primary functional abnormality. Diabetologia. 2009; 52:1003-12.

5. Tierney EF, Cadwell BL, Engelgau MM, Shireley L, Parsons SL, Moum K, Geiss LS. Declining mortality rate among people with diabetes in North Dakota, 1997-2002. Diabetes Care. 2004; 27:2723-25.

6. Handelsman Y, Mechanick JI, Blonde L, Grunberger G, Bloomgarden ZT, Bray GA, Dagogo-Jack S, Davidson JA, Einhorn D, Ganda O, Garber AJ, Hirsch IB, Horton ES, et al; and AACE Task Force for Developing a Diabetes Comprehensive Care Plan. American Association of Clinical Endocrinologists Medical Guidelines for clinical practice for developing a diabetes mellitus comprehensive care plan: executive summary. Endocr Pract. 2011; 17:287-302

7. Wajchenberg BL. beta-cell failure in diabetes and preservation by clinical treatment. Endocr Rev. 2007; 28:187-218

8. Menke A, Guallar E, Cowie CC. Metals in Urine and Diabetes in U.S. Adults. Diabetes. 2016; 65:164-71.

9. Thayer KA, Heindel JJ, Bucher JR, Gallo MA. Role of environmental chemicals in diabetes and obesity: a National Toxicology Program workshop review. Environ Health Perspect. 2012; 120:779-89.

10. Maull EA, Ahsan H, Edwards J, Longnecker MP, NavasAcien A, Pi J, Silbergeld EK, Styblo M, Tseng CH, Thayer KA, Loomis D. Evaluation of the association between arsenic and diabetes: a National Toxicology Program workshop review. Environ Health Perspect. 2012; 120:1658-70.

11. Järup L, Berglund M, Elinder CG, Nordberg G, Vahter M. Health effects of cadmium exposure - a review of the literature and a risk estimate. Scand J Work Environ Health. 1998 (Suppl 1); 24:1-51.

12. Järup L, Akesson A. Current status of cadmium as an environmental health problem. Toxicol Appl Pharmacol. 2009; 238:201-08.

13. Xun P, Liu K, Daviglus M, Morris S, He K. Cadmium exposure and incidence of diabetes: findings from the cardia trace element study. Diabetes. 2013; 62:A21.

14. Wallia A, Allen NB, Badon S, El Muayed M. Association between urinary cadmium levels and prediabetes in the NHANES 2005-2010 population. Int J Hyg Environ Health. 2014; 217:854-60.

15. Schwartz GG, Il'yasova D, Ivanova A. Urinary cadmium, impaired fasting glucose, and diabetes in the NHANES III. Diabetes Care. 2003; 26:468-70.
16. Tangvarasittichai S, Niyomtam S, Meemark S, Pingmuangkaew P, Nunthawarasilp P. Elevated cadmium exposure associated with hypertension, diabetes and chronic kidney disease, in the population of cadmiumcontaminated area. International Journal of Toxicological and Pharmacological Research. 2015; 7:50-56.

17. Romano ME, Enquobahrie DA, Simpson CD, Checkoway H, Williams MA. A Case-Cohort Study of Cadmium Body Burden and Gestational Diabetes Mellitus in American Women. Environ Health Perspect. 2015; 123:993-98.

18. Peng S, Liu L, Zhang X, Heinrich J, Zhang J, Schramm KW, Huang Q, Tian M, Eqani SA, Shen H. A nested casecontrol study indicating heavy metal residues in meconium associate with maternal gestational diabetes mellitus risk. Environ Health. 2015; 14:19.

19. Son HS, Kim SG, Suh BS, Park DU, Kim DS, Yu SD, Hong YS, Park JD, Lee BK, Moon JD, Sakong J. Association of cadmium with diabetes in middle-aged residents of abandoned metal mines: the first health effect surveillance for residents in abandoned metal mines. Ann Occup Environ Med. 2015; 27:20.

20. Haswell-Elkins M, Imray P, Satarug S, Moore MR, O'dea K. Urinary excretion of cadmium among Torres Strait Islanders (Australia) at risk of elevated dietary exposure through traditional foods. J Expo Sci Environ Epidemiol. 2007; 17:372-77.

21. Nie X, Wang N, Chen Y, Chen C, Han B, Zhu C, Chen Y, Xia F, Cang Z, Lu M, Meng Y, Jiang B, D Jensen M, Lu Y. Blood cadmium in Chinese adults and its relationships with diabetes and obesity. Environ Sci Pollut Res Int. 2016; 23:18714-23.

22. Swaddiwudhipong W, Nguntra P, Kaewnate Y, Mahasakpan P, Limpatanachote P, Aunjai T, Jeekeeree W, Punta B, Funkhiew T, Phopueng I. Human Health Effects from Cadmium Exposure: Comparison between Persons Living in Cadmium-Contaminated and Non-Contaminated Areas in Northwestern Thailand. Southeast Asian J Trop Med Public Health. 2015; 46:133-42.

23. Swaddiwudhipong W, Mahasakpan P, Limpatanachote P, Krintratun S. Correlations of urinary cadmium with hypertension and diabetes in persons living in cadmiumcontaminated villages in northwestern Thailand: A population study. Environ Res. 2010; 110:612-16.

24. Swaddiwudhipong W, Limpatanachote P, Nishijo M, Honda R, Mahasakpan P, Krintratun S. Cadmiumexposed population in Mae Sot district, Tak province: 3. Associations between urinary cadmium and renal dysfunction, hypertension, diabetes, and urinary stones. J Med Assoc Thai. 2010; 93:231-8.

25. Shapiro GD, Dodds L, Arbuckle TE, Ashley-Martin J, Fraser W, Fisher M, Taback S, Keely E, Bouchard MF, Monnier P, Dallaire R, Morisset A, Ettinger AS. Exposure to phthalates, bisphenol A and metals in pregnancy and the association with impaired glucose tolerance and gestational 
diabetes mellitus: the MIREC study. Environ Int. 2015; 83:63-71.

26. Moon SS. Association of lead, mercury and cadmium with diabetes in the Korean population: the Korea National Health and Nutrition Examination Survey (KNHANES) 2009-2010. Diabet Med. 2013; 30:e143-48.

27. Liu B, Feng W, Wang J, Li Y, Han X, Hu H, Guo H, Zhang X, He M. Association of urinary metals levels with type 2 diabetes risk in coke oven workers. Environ Pollut. 2016; 210:1-8.

28. Feng W, Cui X, Liu B, Liu C, Xiao Y, Lu W, Guo H, He M, Zhang X, Yuan J, Chen W, Wu T. Association of urinary metal profiles with altered glucose levels and diabetes risk: a population-based study in China. PLoS One. 2015; 10:e0123742.

29. Borné Y, Fagerberg B, Persson M, Sallsten G, Forsgard N, Hedblad B, Barregard L, Engström G. Cadmium exposure and incidence of diabetes mellitus - results from the Malmö Diet and Cancer study. PLoS One. 2014; 9:e112277.

30. Barregard L, Bergström G, Fagerberg B. Cadmium exposure in relation to insulin production, insulin sensitivity and type 2 diabetes: a cross-sectional and prospective study in women. Environ Res. 2013; 121:104-09.

31. Li XT, Yu PF, Gao Y, Guo WH, Wang J, Liu X, Gu AH, Ji GX, Dong Q, Wang BS, Cao Y, Zhu BL, Xiao H. Association between Plasma Metal Levels and Diabetes Risk: a Case-control Study in China. Biomed Environ Sci. 2017; 30:482-91.

32. Moher D, Liberati A, Tetzlaff J, Altman DG, Group P, and PRISMA Group. Preferred reporting items for systematic reviews and meta-analyses: the PRISMA statement. BMJ. 2009; 339:b2535.

33. El Husseiny NM, Said ES, El Shahat Mohamed N, Othman AI. Impact of trace element changes on dehydroepiandrosterone sulfate in healthy and diabetic states among middle-age and elderly Egyptians. Biol Trace Elem Res. 2011; 143:1451-60.

34. Bunio A, Szygula R, Tubek S, Krasowski G. The content of elements in rainwater and its relation to the frequency of hospitalization for diabetes and obesity in Opole Voivodship, Poland, during 2000-2002. Biol Trace Elem Res. 2010; 136:149-56.

35. Akinloye O, Ogunleye K, Oguntibeju OO. Cadmium, lead, arsenic and selenium levels in patients with type 2 diabetes mellitus. Afr J Biotechnol. 2010; 9:5189-95.

36. Afridi HI, Kazi TG, Brabazon D, Naher S, Talpur FN. Comparative metal distribution in scalp hair of Pakistani and Irish referents and diabetes mellitus patients. Clin Chim Acta. 2013; 415:207-214.

37. Adams SV, Barrick B, Christopher EP, Shafer MM, Song $\mathrm{X}$, Vilchis H, Newcomb PA, Ulery A. Urinary heavy metals in Hispanics 40-85 years old in Doña Ana County, New Mexico. Arch Environ Occup Health. 2016; 71:338-346.

38. Edwards J, Ackerman C. A Review of Diabetes Mellitus and Exposure to the Environmental Toxicant Cadmium with an
Emphasis on Likely Mechanisms of Action. Curr Diabetes Rev. 2015.

39. Edwards JR, Prozialeck WC. Cadmium, diabetes and chronic kidney disease. Toxicol Appl Pharmacol. 2009; 238:289-93.

40. Kuo CC, Moon K, Thayer KA, Navas-Acien A. Environmental chemicals and type 2 diabetes: an updated systematic review of the epidemiologic evidence. Curr Diab Rep. 2013; 13:831-49.

41. Kim NH, Hyun YY, Lee KB, Chang Y, Ryu S, Oh KH, Ahn C. Environmental heavy metal exposure and chronic kidney disease in the general population. J Korean Med Sci. 2015; 30:272-77.

42. Barregard L, Bergström G, Fagerberg B. Cadmium, type 2 diabetes, and kidney damage in a cohort of middle-aged women. Environ Res. 2014; 135:311-16.

43. Cheng X, Niu Y, Ding Q, Yin X, Huang G, Peng J, Song J. Cadmium Exposure and Risk of Any Fracture: A PRISMACompliant Systematic Review and Meta-Analysis. Medicine (Baltimore). 2016; 95:e2932.

44. James KA, Meliker JR. Environmental cadmium exposure and osteoporosis: a review. Int J Public Health. 2013; 58:737-45.

45. Navas-Acien A, Tellez-Plaza M, Guallar E, Muntner P, Silbergeld E, Jaar B, Weaver V. Blood cadmium and lead and chronic kidney disease in US adults: a joint analysis. Am J Epidemiol. 2009; 170:1156-64.

46. Zhang Y, Liang X, Chen W, Wang J, Huang Q, Chen Z, Wang P, Huang R, Hu S, Li Z, Tang L, Wang G, Yang F, et al. Long-term effect of cadmium exposure on residents' renal dysfunction: an epidemiologic study. [Article in Chinese] Zhonghua Yu Fang Yi Xue Za Zhi. 2015; 49:638-43.

47. Fagerberg B, Kjelldahl J, Sallsten G, Barregard L, Forsgard N, Österberg K, Hultén LM, Bergström G. Cadmium exposure as measured in blood in relation to macrophage density in symptomatic atherosclerotic plaques from human carotid artery. Atherosclerosis. 2016; 249:209-14.

48. Bergström G, Fagerberg B, Sallsten G, Lundh T, Barregard L. Is cadmium exposure associated with the burden, vulnerability and rupture of human atherosclerotic plaques? PLoS One. 2015; 10:e0121240.

49. Song J, Luo H, Yin X, Huang G, Luo S, Lin R, Yuan DB, Zhang W, Zhu J. Association between cadmium exposure and renal cancer risk: a meta-analysis of observational studies. Sci Rep. 2015; 5:17976.

50. Ju-Kun S, Yuan DB, Rao HF, Chen TF, Luan BS, Xu XM, Jiang FN, Zhong WD, Zhu JG. Association Between Cd Exposure and Risk of Prostate Cancer: A PRISMACompliant Systematic Review and Meta-Analysis. Medicine (Baltimore). 2016; 95:e2708.

51. Larsson SC, Wolk A. Urinary cadmium and mortality from all causes, cancer and cardiovascular disease in the general population: systematic review and meta-analysis of cohort studies. Int J Epidemiol. 2015. 
52. Hecht EM, Landy DC, Ahn S, Hlaing WM, Hennekens $\mathrm{CH}$. Hypothesis: cadmium explains, in part, why smoking increases the risk of cardiovascular disease. J Cardiovasc Pharmacol Ther. 2013; 18:550-54.

53. Bell RR, Early JL, Nonavinakere VK, Mallory Z. Effect of cadmium on blood glucose level in the rat. Toxicol Lett. 1990; 54:199-205.

54. Afridi HI, Kazi TG, Kazi N, Jamali MK, Arain MB, Jalbani N, Baig JA, Sarfraz RA. Evaluation of status of toxic metals in biological samples of diabetes mellitus patients. Diabetes Res Clin Pract. 2008; 80:280-88.

55. Swaddiwudhipong W, Limpatanachote P, Mahasakpan P, Krintratun S, Punta B, Funkhiew T. Progress in cadmiumrelated health effects in persons with high environmental exposure in northwestern Thailand: a five-year follow-up. Environ Res. 2012; 112:194-98.

56. Fowler BA. Monitoring of human populations for early markers of cadmium toxicity: a review. Toxicol Appl Pharmacol. 2009; 238:294-300.

57. Prozialeck WC, Edwards JR. Early biomarkers of cadmium exposure and nephrotoxicity. Biometals. 2010; 23:793-809.

58. El Muayed M, Raja MR, Zhang X, MacRenaris KW, Bhatt S, Chen X, Urbanek M, O'Halloran TV, Lowe WL Jr. Accumulation of cadmium in insulin-producing $\beta$ cells. Islets. 2012; 4:405-16.

59. Chen YW, Yang CY, Huang CF, Hung DZ, Leung YM, Liu $\mathrm{SH}$. Heavy metals, islet function and diabetes development. Islets. 2009; 1:169-76.

60. Chang KC, Hsu CC, Liu SH, Su CC, Yen CC, Lee MJ, Chen KL, Ho TJ, Hung DZ, Wu CC, Lu TH, Su YC, Chen YW, Huang CF. Cadmium induces apoptosis in pancreatic $\beta$-cells through a mitochondria-dependent pathway: the role of oxidative stress-mediated c-Jun N-terminal kinase activation. PLoS One. 2013; 8:e54374.

61. Brown C. Arsenic exposure linked to diabetes risk in Canada. CMAJ. 2015;187: E438-E439.
62. Feseke SK, St-Laurent J, Anassour-Sidi E, Ayotte P, Bouchard M, Levallois P. Arsenic exposure and type 2 diabetes: results from the 2007-2009 Canadian Health Measures Survey. Health Promot Chronic Dis Prev Can. 2015; 35:63-72.

63. Andra SS, Kalyvas H, Andrianou XD, Charisiadis $\mathrm{P}$, Christophi CA, Makris KC. Preliminary evidence of the association between monochlorinated bisphenol A exposure and type II diabetes mellitus: A pilot study. J Environ Sci Health A Tox Hazard Subst Environ Eng. 2015; 50:243-59.

64. Lamb RE, Goldstein BJ. Modulating an oxidativeinflammatory cascade: potential new treatment strategy for improving glucose metabolism, insulin resistance, and vascular function. Int J Clin Pract. 2008; 62:1087-95.

65. Kurata Y, Katsuta O, Doi T, Kawasuso T, Hiratsuka H, Tsuchitani M, Umemura T. Chronic cadmium treatment induces islet B cell injury in ovariectomized cynomolgus monkeys. Jpn J Vet Res. 2003; 50:175-83.

66. Lei LJ, Jin TY, Zhou YF. Insulin expression in rats exposed to cadmium. Biomed Environ Sci. 2007; 20:295-301.

67. Hartling L, Milne A, Hamm MP, Vandermeer B, Ansari M, Tsertsvadze A, Dryden DM. Testing the Newcastle Ottawa Scale showed low reliability between individual reviewers. J Clin Epidemiol. 2013; 66:982-93.

68. DerSimonian R, Laird N. Meta-analysis in clinical trials. Control Clin Trials. 1986; 7:177-88.

69. Begg CB, Mazumdar M. Operating characteristics of a rank correlation test for publication bias. Biometrics. 1994; 50:1088-101.

70. Egger M, Davey Smith G, Schneider M, Minder C. Bias in meta-analysis detected by a simple, graphical test. BMJ. 1997; 315:629-34. 